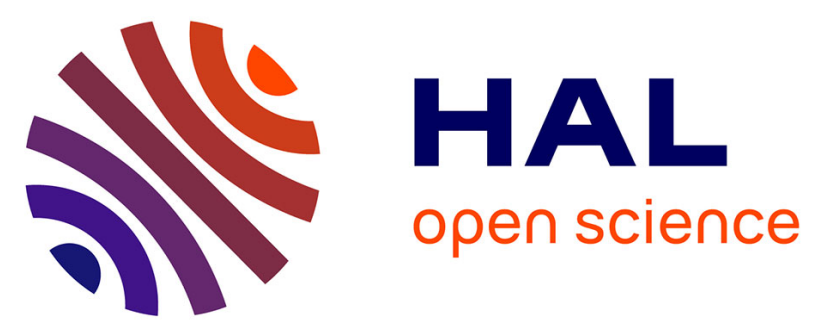

\title{
Screening of biological properties of MoV2O2S2- and MoV2O4-based coordination complexes: Investigation of antibacterial, antifungal, antioxidative and antitumoral activities versus growing of Spirulina platensis biomass
}

Arcadie Fuior, Akram Hijazi, Olga Garbuz, Valentina Bulimaga, Liliana

Zosim, Diana Cebotari, Mohamed Haouas, Ion Toderaş, Aurelian Gulea, Sébastien Floquet

\section{- To cite this version:}

Arcadie Fuior, Akram Hijazi, Olga Garbuz, Valentina Bulimaga, Liliana Zosim, et al.. Screening of biological properties of MoV2O2S2- and MoV2O4-based coordination complexes: Investigation of antibacterial, antifungal, antioxidative and antitumoral activities versus growing of Spirulina platensis biomass. Journal of Inorganic Biochemistry, In press, pp.111627. 10.1016/j.jinorgbio.2021.111627 . hal-03393528

\author{
HAL Id: hal-03393528 \\ https://hal.science/hal-03393528
}

Submitted on 21 Oct 2021

HAL is a multi-disciplinary open access archive for the deposit and dissemination of scientific research documents, whether they are published or not. The documents may come from teaching and research institutions in France or abroad, or from public or private research centers.
L'archive ouverte pluridisciplinaire HAL, est destinée au dépôt et à la diffusion de documents scientifiques de niveau recherche, publiés ou non, émanant des établissements d'enseignement et de recherche français ou étrangers, des laboratoires publics ou privés.

$$
\text { Copyright }
$$




\title{
Screening of biological properties of $\mathrm{Mo}_{2}{ }_{2} \mathrm{O}_{2} \mathrm{~S}_{2}$ - and $\mathrm{Mo}_{2}{ }_{2} \mathrm{O}_{4}$-based coordination complexes: investigation of antibacterial, antifungal, antioxidative and antitumoral activities versus growing of Spirulina platensis biomass
}

\author{
Arcadie Fuior, ${ }^{\mathrm{a}, \mathrm{b}}$ Akram Hijazi, ${ }^{\mathrm{a}}$ Olga Garbuz, ${ }^{\mathrm{b}}$ Valentina Bulimaga, ${ }^{\mathrm{b}}$ Liliana Zosim, ${ }^{\mathrm{b}}$ Diana \\ Cebotari, ${ }^{\mathrm{a}, \mathrm{b}}$ Mohamed Haouas, ${ }^{\mathrm{a}}$ Ion Toderaş, ${ }^{\mathrm{c}}$ Aurelian Gulea, ${ }^{\mathrm{b}, *}$ and Sébastien Floquet, ${ }^{\mathrm{a}, *}$ \\ a Institut Lavoisier de Versailles, CNRS UMR 8180, Univ. Versailles Saint Quentin en Yvelines, \\ Université Paris-Saclay, 45 av. des Etats-Unis, 78035 Versailles cedex (France) \\ ${ }^{b}$ State University of Moldova, 60 Alexei Mateevici str., MD-2009 Chisinau, Republic of \\ Moldova \\ c Institute of Zoology, 1 Academiei str., MD-2028 Chisinau, Republic of Moldova
}

E-mails: sebastien.floquet@uvsq.fr, guleaaurelian@gmail.com

\begin{abstract}
This paper deals with the biological potential of coordination compounds based on binuclear core $\left[\mathrm{Mo}_{2} \mathrm{O}_{2} \mathrm{E}_{2}\right]^{2+}$ $(\mathrm{E}=\mathrm{O}$ or $\mathrm{S})$ coordinated with commercially available ligands such as oxalates $\left(\mathrm{Ox}^{2-}\right)$, L-cysteine $\left(\mathrm{L}-\mathrm{cys}^{2-}\right), \mathrm{L}-$ histidine (L-his-), Iminodiacetate (IDA $\left.{ }^{2-}\right)$, Nitrilotriacetate $\left(\mathrm{HNTA}^{2-}\right.$ or $\mathrm{NTA}^{3-}$ ) or ethylenediamine tetraacetate $\left(\right.$ EDTA $\left.^{4-}\right)$ by means of various in vitro assays in a screening approach. Results suggest that the obtained complexes show weak antibacterial and antifungal properties while not being cytotoxic on cancerous and mammalian cells. In contrast, $\left[\mathrm{Mo}_{2} \mathrm{O}_{2} \mathrm{E}_{2}(\mathrm{~L}-\mathrm{cys})_{2}\right]^{2-}$ complexes stand out as powerful antioxidant, whereas $\left[\mathrm{Mo}_{2} \mathrm{O}_{2} \mathrm{E}_{2}(\mathrm{EDTA}]^{2-}\right.$ associating tetraphenylphosphonium counter-cations display strong antibiotic activity. Finally, some complexes have evidenced a positive activity towards the growing of spirulina platensis together with a modification of the proportions of biological components inside the cells. These findings reveal promising bioactivity of the bridged binuclear $\mathrm{Mo}^{(+\mathrm{V})}$ cores inside complexes and encourage further research for new highly active yet non-toxic molecules for biomedical applications.
\end{abstract}

Keywords : Molybdedum, cluster, complex, cytotoxicity, antibiotic activity, spirulina platensis

\section{Introduction}

Molybdenum is an essential microelement since it is found at the heart of molybdoenzymes, so much vital for the living organisms.[1-4] Nitrogen assimilation by plants,[5,6] vitamin A formation in mammals, [7] and many other crucial biological redox processes in nature are efficiently performed by these metalloproteins that incorporate a $\mathrm{Mo}(+\mathrm{VI})$ or a $\mathrm{Mo}(+\mathrm{V})$ cation usually surrounded by $\mathrm{O}, \mathrm{N}$ and $\mathrm{S}$ atoms, which can finely tune its electronic properties and the redox processes, passing through $\mathrm{Mo}(+\mathrm{V})$ and $\mathrm{Mo}(+\mathrm{IV})$ atoms.[8] Since this metal plays an active and important role in the metabolism of the majority of Earth's life forms, this makes molybdenum very interesting for biochemical and biomedical research and many authors have developed numerous very simple coordination complexes with molybdenum cores in the seventies and eighties to mimic such enzymes.[9-16] Developing new Mo-based compounds is indeed a good strategy to achieve promising drugs or biomimetic molecules. For this purpose, coordination compounds of dimolybdic $\left[\mathrm{Mo}^{(\mathrm{V})}{ }_{2} \mathrm{O}_{2} \mathrm{E}_{2}\right]^{2+}(\mathrm{E}=\mathrm{O}$ or $\mathrm{S})$ cores with simple ligands containing carboxylate and amine functions like EDTA, $\mathrm{H}_{3} \mathrm{NTA}, \mathrm{H}_{2}$ IDA, L-cysteine, L-histidine and others have been widely investigated.[17-19] In particular, since $\mathrm{Mo}^{(+\mathrm{V})}$ binuclear complexes were interesting as models for redox active centers of molybdoenzymes, detailed electrochemical studies were performed in aqueous 
or in organic solvents to show the reversible or quasi-reversible cyclic processes of step-by-step one-electron reduction of the two $\mathrm{Mo}^{(+\mathrm{V})}$ atoms to $\mathrm{Mo}^{(+\mathrm{IV})}$ in the $\left[\mathrm{Mo}_{2} \mathrm{O}_{2} \mathrm{E}_{2}\right]^{2+}$ core in non-aqueous media.[20-23] However, surprisingly, to the best of our knowledge, no direct biological properties of $\left[\mathrm{Mo}_{2} \mathrm{O}_{2} \mathrm{~S}_{2}\right]^{2+}$ and $\left[\mathrm{Mo}_{2} \mathrm{O}_{4}\right]^{2+}-$ based complexes were reported until a recent paper of Gretarsdóttir et al. in which six simple complexes combining the $\left[\mathrm{Mo}_{2} \mathrm{O}_{2} \mathrm{~S}_{2}\right]^{2+}$ core and ligands such as disulfides, tetrasulfides, cyclopentadiene Cp, DMF, Serine, Cysteine or threonine have been suggested to have biological potential. Their convenient low cytotoxicity on cells was considered useful for possible therapeutic applications like the development of catalytic drugs.[24]

In the last two decades, we acquired a strong expertise in the chemistry of such dimolybdic cores, which are used in the domain of polyoxometalates as building block for the synthesis of supramolecular assemblies,[25,26] some of them being capable of exhibiting electrocatalytic properties for the reduction of protons.[27,28] Furthermore, more recently we have patented results showing that such complexes can stimulate activity of microalgae Spirulina platensis. [29] The compound $\left.\left[\mathrm{Mo}_{2} \mathrm{O}_{2} \mathrm{~S}_{2} \text { (IDA) }\right]_{2}\right]^{2-}$ was indeed proved to regulate the ratio of acid and sulfate polysaccharides (up to $46 \%$ and respectively $100 \%$ more compared to a $\mathrm{MoO}_{3}$ solution at the same mass concentration) in the total carbohydrate composition of the cultivated spirulina cyanobacteria.[29] These promising results prompted us to investigate more widely the biological activities of two series of $\left[\mathrm{Mo}_{2} \mathrm{O}_{2} \mathrm{E}_{2}\right]^{2+}$ coordination complexes either with $\mathrm{E}=\mathrm{S}$ or $\mathrm{E}=\mathrm{O}$. Herein we first present the synthesis and characterization of 13 complexes (see Figure 1) combining such dimolybdic cores with ligands like oxalates (Ox), L-cysteine (L-cys), L-histidine (L-his), Iminodiacetate (IDA), Nitrilotriacetate (NTA) or ethylenediamine tetraacetate (EDTA) with a new synthetic route followed for sulfurated compounds. The complexes were characterized in the solid state by FT-IR and elemental analysis and in solution by ESI-MS and NMR which bring interesting results about the dynamics of such compounds in solution. A second part is devoted to biological screening tests allowing to investigate their potentialities for applications.

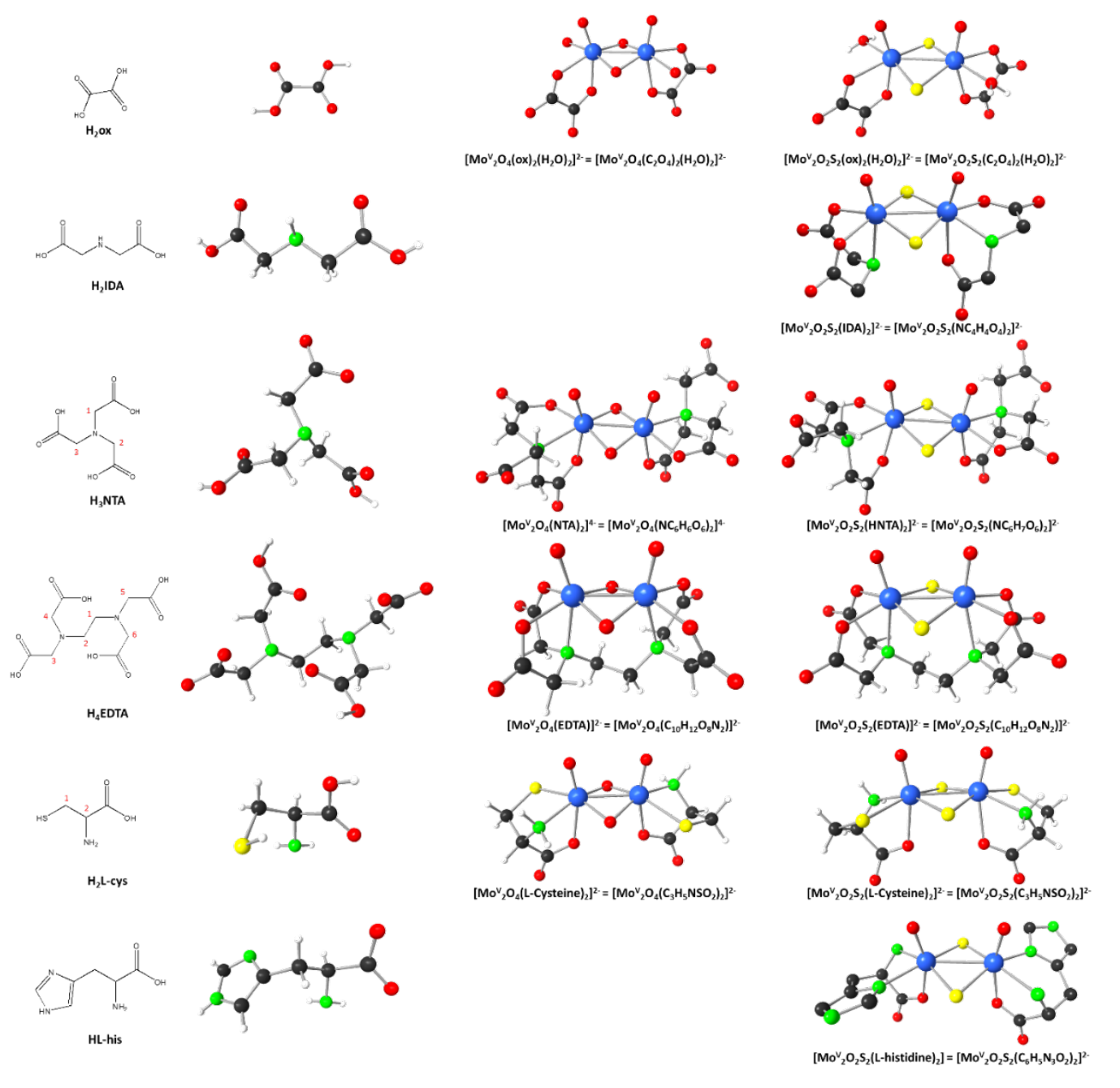




\section{Results and discussion}

\subsection{Syntheses}

The synthesis of $\mathrm{Mo}_{2} \mathrm{O}_{4}$-based complexes has followed the classical strategy of sodium molybdate $\mathrm{Na}_{2} \mathrm{MoO}_{4}$ interacting with ligands $\mathrm{H}_{2} \mathrm{Ox}, \mathrm{H}_{3} \mathrm{NTA}, \mathrm{H}_{4}$ EDTA, $\mathrm{H}_{2}$-L-cys, H-L-his ligands in the presence of a reducing agent (usually hydrazine or dithionite) in aqueous solution at room temperature or at moderate heating.[17] On the other hand, compounds containing the di- $\mu$-sulfido bridged unit $\left[\mathrm{Mo}_{2}{ }_{2} \mathrm{O}_{2} \mathrm{~S}_{2}\right]^{2+}$ were synthesized according to a method very different from those usually described in the literature which are often complicated and require strict precautions (long hydrosulfuration, specific reflux conditions in organic solvents, slow crystallization under inert atmosphere). The one pot synthesis used here avoids these problems by employing the $\mathrm{K}_{1.5}\left(\mathrm{NMe}_{4}\right)_{0.5}\left[\mathrm{I}_{2} \mathrm{Mo}_{10} \mathrm{O}_{10} \mathrm{~S}_{10}(\mathrm{OH})_{10}\left(\mathrm{H}_{2} \mathrm{O}\right)_{5}\right] \cdot 20 \mathrm{H}_{2} \mathrm{O}$ solid precursor which generates $\left[\mathrm{Mo}_{2} \mathrm{O}_{2} \mathrm{~S}_{2}\right]^{2+}$ species in acidic aqueous by hydrolysis of the bridging hydroxo groups.[39] The resulting red-orange solution then reacts with the ligand, which is introduced in excess in order to avoid the formation of cyclic compounds, well-known with this cluster.[26,28,33,39-41] $\mathrm{Mo}_{2} \mathrm{O}_{2} \mathrm{~S}_{2}$-based complexes are obtained preferably as $\mathrm{K}^{+}$salts, while the oxo homologues are more easily prepared in the form of $\mathrm{Na}^{+}$salts. The corresponding synthetic procedures are detailed in the experimental section given in the Supporting Information (SI). The compounds are isolated in the solid state and characterized by FT-IR, EDX, Elemental analysis, TGA, ESI-MS and NMR. In the following of this paper, for clarity, they will be denoted by the general notation "cation-core-ligand". Some are obtained as single crystals and the new structures are discussed below.

\subsection{Structure of TBA-Mo2 $\mathrm{O}_{2} \mathrm{~S}_{2}$-IDA}

The $\left[\mathrm{Mo}_{2} \mathrm{O}_{2} \mathrm{~S}_{2}(\mathrm{IDA})_{2}\right]^{2-}$ complex was obtained with difficulty in solid state, compared to the other $\mathrm{Mo}_{2} \mathrm{O}_{2} \mathrm{~S}_{2}-$ based complexes and also to its oxo analogue which couldn't be isolated. A powder has been isolated only as $\mathrm{PPh}_{4}^{+}$salt, while single crystals were collected from a highly concentrated solution close to dryness containing an excess of $\mathrm{TBA}^{+}$cations. In contrast with the other complexes, the molecular structure of the anionic complex $\left.\left[\mathrm{Mo}_{2} \mathrm{O}_{2} \mathbf{S}_{2} \text { (IDA) }\right)_{2}\right]^{2-}$ depicted in Figure 2 was not known. The single dinuclear unit $\left\{\mathrm{Mo}_{2} \mathrm{O}_{2} \mathrm{~S}_{2}\right\}$ contains two iminodiacetate ligands (IDA ${ }^{2-}$ ) coordinated to the $\mathrm{Mo}(\mathrm{V})$ centers, but the coordination modes of both iminodiacetato ligands are not equivalent and the resulting complex is chiral. Both ligands coordinate to $\mathrm{Mo}^{\mathrm{V}}$ centers through two oxygen atoms of the two carboxylate functions of IDA ${ }^{2-}$ and by the central nitrogen atom. The difference comes from the coordination mode of the latter. In a first ligand, $\mathrm{N}$ atom occupies the apical position in trans configuration with the $\mathrm{Mo}=\mathrm{O}$ bond. In the other ligand, this atom coordinates $\mathrm{Mo}$ in an equatorial position, which constitutes an unusual coordination mode in this family of complexes to our knowledge. As shown in Figure $2 \mathrm{~b}$, in the solid state, both enantiomers are found in the crystal cell to give a racemic crystal. According to literature data for $\left[\mathrm{Mo}_{2} \mathrm{O}_{2} \mathrm{~S}_{2}\right]$-based architectures,[26] the Mo-Mo distance of $2.84 \AA$ is typical of an Mo-Mo bond, the Mo$\mathrm{O}$ distances with terminal oxygen atoms are found in the range 1.67-1.69 $\AA$ and are characteristic of $\mathrm{Mo}^{\mathrm{V}}=\mathrm{O}$ bond and the Mo-S distances with the bridging sulfido ions are also in the usual range for the expected values (Mo-S = 2.31-2.33 $\AA$ ). Concerning the coordination bonds of the two ligands, each of them is coordinated by the amino group either in equatorial (Mo-N = 2.24 $\AA$ ) or in axial position (Mo-N $=2.40 \AA$ ) and by the two carboxylate functions in equatorial ( $\mathrm{Mo}-\mathrm{O}=2.11-2.13 \AA$ ) or in axial position $(\mathrm{Mo}-\mathrm{O}=2.24 \AA$ ). The ligands are twofold deprotonated to give the anionic $\left[\mathbf{M o}_{2} \mathrm{O}_{2} \mathbf{S}_{2}(\text { IDAA) })^{2-}\right.$ complex by combination with the $\left[\mathrm{Mo}_{2} \mathrm{O}_{2} \mathrm{~S}_{2}\right]^{2+}$ unit. This assumption is supported by the fact that two additional tetrabutylammonium cations are found in the structure and by IR spectrum which do not indicate the presence of any vibration in the $1700-1750 \mathrm{~cm}^{-1}$ range, typical of protonated carboxylic function. Crystallographic data of the structure is given in SI. 


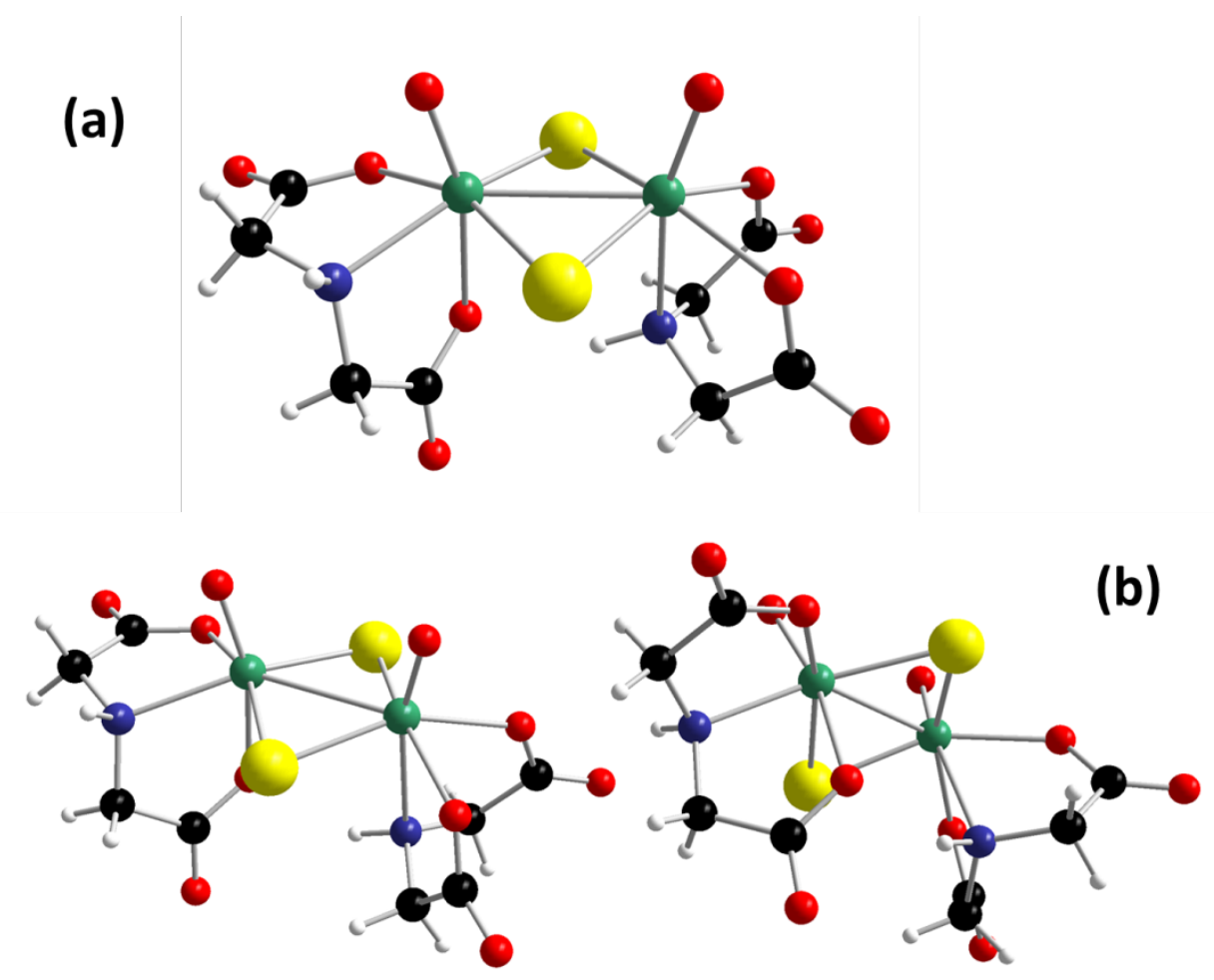

Figure 2. (a) Molecular Structure of the complex $\left[\mathrm{Mo}_{2} \mathrm{O}_{2} \mathrm{~S}_{2}(I D A)_{2}\right]^{2-}$, (b) View of the two isomers of the complex $\left[\mathrm{Mo}_{2} \mathrm{O}_{2} \mathrm{~S}_{2}(I D A)_{2}\right]^{2-}$ in the crystal cell

\subsection{Solution studies}

The complexes were characterized in solution by ${ }^{1} \mathrm{H}$-NMR spectroscopy and by ${ }^{1} \mathrm{H}$ DOSY-NMR technique, in deuterated water and DMSO (see Supporting Information) at a concentration of $5 \mathrm{mM}$. Note that, since the complex $\mathbf{M o}_{2} \mathrm{O}_{2} \mathbf{S}_{2}-\mathbf{L}-$ his is neutral and that the oxalate containing complexes $\mathbf{C s}-\mathrm{Mo}_{2} \mathbf{O}_{2} \mathbf{S}_{2}-\mathbf{o x}$ and $\mathbf{N a -}-\mathbf{M o}_{2} \mathrm{O}_{4}-\mathbf{o x}$ do not have protons, they are logically excluded from this ${ }^{1} \mathrm{H}$ NMR study.

The ${ }^{1} \mathrm{H}$-NMR spectra of $\mathrm{Mo}_{2} \mathrm{O}_{4}$ and $\mathrm{Mo}_{2} \mathrm{O}_{2} \mathrm{~S}_{2}$ based complexes in $\mathrm{D}_{2} \mathrm{O}$ are given in figures 3 and 4 , while the NMR spectra recorded in DMSO are given in Figure S4 in SI. In aqueous solution, complexes K-Mo $\mathbf{M o}_{2} \mathbf{O}_{2} \mathbf{S}_{2}$-EDTA and $\mathbf{K}-\mathrm{Mo}_{2} \mathrm{O}_{2} \mathbf{S}_{2}$-L-cys give spectra with fine peaks which can be assigned to the protons of coordinated ligands in frozen geometries. The signals of methylenic protons of L-cysteine ligands in $\mathbf{K}-\mathrm{Mo}_{2} \mathrm{O}_{2} \mathrm{~S}_{2}-\mathrm{L}$-cys have shifted from around $3 \mathrm{ppm}$ in the free ligand to $2.9 \mathrm{ppm}$ and $3.5 \mathrm{ppm}$, and the proton on the tertiary carbon atom initially found at $3.9 \mathrm{ppm}$ is now downfield by $0.6 \mathrm{ppm}$. In the case of $\mathbf{K}-\mathbf{M o}_{2} \mathbf{O}_{2} \mathbf{S}_{2}$-EDTA, chelation of EDTA ligand to the metal centers leads to a more intricate spectrum, from only 2 singlets in the free ligand to 3 pairs of doublets of the same intensity. The NMR spectrum evidences a symmetry lower in solution than the expected $\mathrm{C}_{2 \mathrm{v}}$ of the frozen structure depicted in Figure 1. Anyway, both complexes show no sign of free ligand, excluding the possibility of decoordination.

In contrast, the identification of peaks seems impossible for $\mathbf{K}-\mathbf{M o}_{2} \mathbf{O}_{2} \mathbf{S}_{2}$-HNTA. For the latter, the peak at 3.8 ppm assigned to a small proportion of uncoordinated ligand and the large signals suggest partial decoordination of the complex and also dynamic properties of the HNTA ligands. This result is consistent with the NMR study published in 2010, where it was suggested that the methylene groups give broad and poorly resolved signals because of dynamic equilibria between the cis and trans isomers passing through partial decoordination of one ligand and thus the presence of free ligand and consequently of monocoordinated complex $\left[\mathrm{Mo}_{2} \mathrm{O}_{2} \mathrm{~S}_{2}(\mathrm{HNTA})\left(\mathrm{H}_{2} \mathrm{O}\right)_{3}\right]^{+}$.[33] The presence of additional isomers such as those obtained with TBA-Mo $\mathbf{M O}_{2} \mathbf{O}_{2} \mathbf{S}_{2}-$ IDA cannot be ruled out either.

When used as building blocks in supramolecular polyoxometalate assemblies, the $\left[\mathrm{Mo}_{2} \mathrm{O}_{2} \mathrm{~S}_{2}\right]^{2+}$ core is usually considered much more labile than its oxo analogue $\left[\mathrm{Mo}_{2} \mathrm{O}_{4}\right]^{2+} \cdot[25,40]$ The same phenomenon is expected in coordination complexes. However, the spectrum of Na-Mo2 $\mathrm{O}_{4}$-EDTA shows something that looks like two very 
broad signals corresponding to the 12 protons of coordinated EDTA ligand, in contrast to its sulfido bridged analogue. The dynamics evidenced for the EDTA ligand in $\mathbf{N a}_{\mathbf{1}}-\mathbf{M o}_{2} \mathbf{O}_{4}$-EDTA preclude any confident assignment of the peaks, even if we can suppose the presence of the peaks of the 6 pairs of non-equivalent protons strongly overlapped. In contrast also with sulfide analogues, the ${ }^{1} \mathrm{H}-\mathrm{NMR}$ spectrum of $\mathbf{K}-\mathbf{M O}_{2} \mathbf{O}_{4}-\mathbf{H N T A}$ displays well resolved signals assigned to coordinated ligands but an important signal of free ligand at 3.8 ppm suggests, as for $\mathbf{K}-\mathrm{Mo}_{2} \mathrm{O}_{2} \mathrm{~S}_{2}-\mathrm{HNTA}$, a decoordination process even at $5 \mathrm{mM}$ concentration (Figure 4). Finally, the case of Na$\mathbf{M o}_{2} \mathbf{O}_{4}-\mathbf{L}$-cys shows a mixture of free ligand and the target complex, in contrast with $\mathbf{K}-\mathbf{M o}_{2} \mathrm{O}_{2} \mathbf{S}_{2}-\mathbf{L}-\mathbf{c y s}$, which displays only the signals of coordinated ligands.

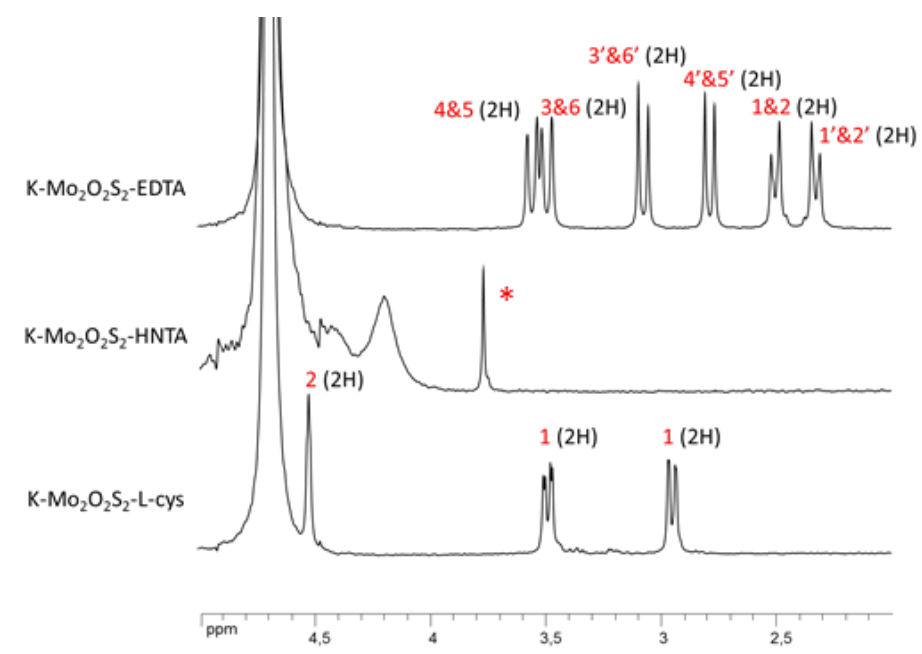

Figure $3^{1} \mathrm{H}$-NMR spectra of $\mathrm{Mo}_{2} \mathrm{O}_{2} \mathrm{~S}_{2}$-based complexes in $\mathrm{D}_{2} \mathrm{O} .{ }^{*}$ indicates the presence of decoordinated ligand.

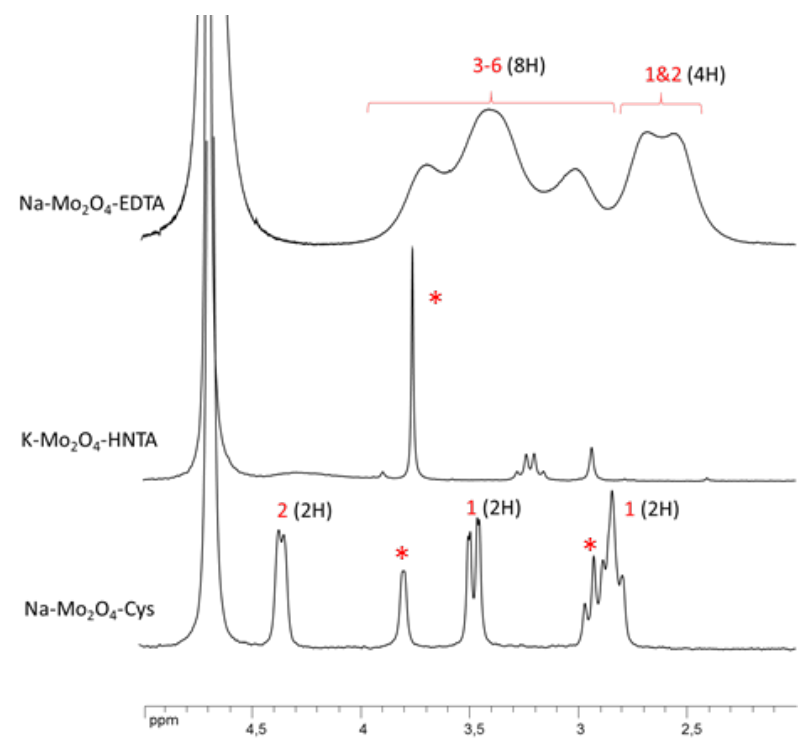

Figure $4{ }^{1} \mathrm{H}-\mathrm{NMR}$ spectra of $\mathrm{Mo}_{2} \mathrm{O}_{4}$-based complexes in $\mathrm{D}_{2} \mathrm{O}$. ${ }^{*}$ indicates the presence of decoordinated ligand.

In summary, these ${ }^{1} \mathrm{H}$-NMR spectra in water evidence a dynamic behavior which is at the opposite of what is usually admitted for these clusters in polyoxometalate chemistry. More dynamics means higher lability, and thus more decoordination/coordination process are observed in $\left[\mathrm{Mo}_{2} \mathrm{O}_{4}\right]$-based coordination complexes. Besides, HNTA complexes exhibit a noticeable presence of free ligand at a concentration of $5 \mathrm{mM}$, which suggest a low chemical stability, as for $\mathbf{N a - M o} \mathbf{O}_{4}-\mathrm{L}-\mathrm{Cys}$.

Changing the solvent can dramatically affect the dynamics of such complexes. By replacing water with DMSO, the dynamics in solution are indeed strongly modified as shown in Figure S4 in SI. In such a medium, the 
decoordination process no longer exists, which renders easier the characterization of these complexes where the

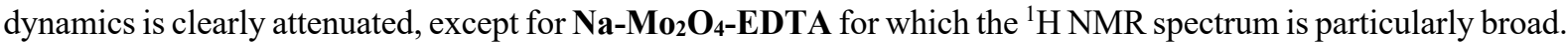
Finally, ${ }^{1} \mathrm{H}$ DOSY NMR is a powerful tool to describe this type of compounds in solution in terms of size and molecular mass and for evidencing dynamic processes and supramolecular interaction in solution.[33,41,42] Besides, as part of a larger project on molybdenum complexes and their associations with cyclodextrins and/or proteins, these values can constitute good reference values. ${ }^{1} \mathrm{H}$ DOSY NMR spectra were recorded in $\mathrm{D}_{2} \mathrm{O}$ and in DMSO. For example, the spectrum obtained for $\mathbf{K}-\mathbf{M o}_{2} \mathrm{O}_{2} \mathbf{S}_{2}$-EDTA is depicted in Figure 5, while the values of self-diffusion coefficient are gathered in the table 1 . The signals give more or less the same value with an average of $515 \pm 6 \mu \mathrm{m}^{2} / \mathrm{s}$ in $\mathrm{D}_{2} \mathrm{O}$. It means that all the signals come from the same molecule, which exclude any decoordination process. Moreover, from Stokes-Einstein law this value allows calculation of a hydrodynamic radius around 0.4-0.5 $\mathrm{nm}$, rather consistent with the expected molecular complexes. Similar values are obtained with the other complexes studied in $\mathrm{D}_{2} \mathrm{O}$, while $\mathrm{D}$ logically decreases to an average of $191 \mu \mathrm{m}^{2} . \mathrm{s}^{-1}$ in more viscous solvent such as DMSO according to the Stokes-Einstein equation.

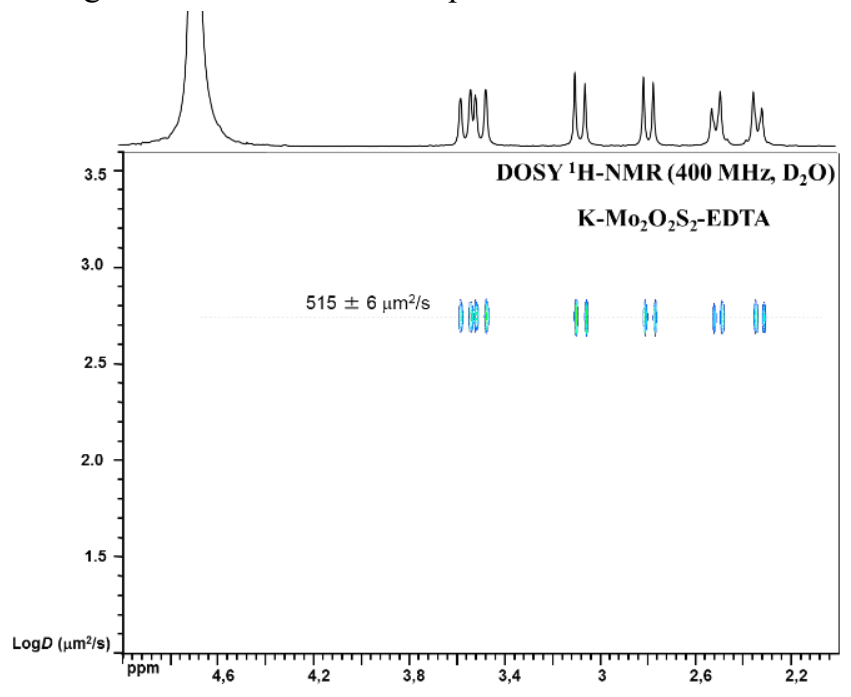

Figure $5{ }^{l} \mathrm{H}$ DOSY NMR spectrum of compound $\mathrm{K}-\mathrm{Mo}_{2} \mathrm{O}_{2} \mathrm{~S}_{2}-\mathrm{EDTA}$ in $\mathrm{D}_{2} \mathrm{O}, 5 \mathrm{mM}$

It is noteworthy for both $\mathbf{K}-\mathrm{Mo}_{2} \mathrm{O}_{2} \mathbf{S}_{2}-\mathbf{H N T A}$ and $\mathbf{K}-\mathrm{Mo}_{2} \mathrm{O}_{4}-\mathbf{H N T A}$ complexes that two sets of D values are identified in $\mathrm{D}_{2} \mathrm{O}$, suggesting the existence of two species with essential difference in size and mass. The peak at $3.8 \mathrm{ppm}$ for $\mathbf{K}-\mathrm{Mo}_{2} \mathbf{O}_{2} \mathbf{S}_{2}-\mathbf{H N T A}$ diffuses at $603 \mu \mathrm{m}^{2} / \mathrm{s}$ and the one at $3.75 \mathrm{ppm}$ for $\mathbf{K}-\mathbf{M o}_{2} \mathbf{O}_{4}-\mathbf{H N T A}$ has a diffusion speed of $623 \mu \mathrm{m}^{2} / \mathrm{s}$, which is significantly high, in agreement with a free ligand in equilibrium with the complex, while the average $\mathrm{D}$ value for this family of compounds with no big differences in size is around 500 in $\mathrm{D}_{2} \mathrm{O}$. The situation is totally changed in DMSO. As shown in figure S5 (SI), only one set of D values is obtained in agreement with a decoordination/coordination process stopped.

Table 1. Self-diffusion coefficients D measured for complexes containing $L$-Cys, HNTA and EDTA ligands in $\mathrm{D}_{2} \mathrm{O}$ and in DMSO (5 mM concentration)

\begin{tabular}{ccc}
\hline Compound & $\mathbf{D}\left(\boldsymbol{\mu m}^{2} / \mathbf{s}\right)$ in $\mathbf{D}_{2} \mathbf{O}$ & $\mathbf{D}\left(\boldsymbol{\mu \mathbf { m } ^ { 2 } / \mathbf { s } ) \text { in DMSO }}\right.$ \\
\hline $\mathrm{K}-\mathrm{Mo}_{2} \mathrm{O}_{2} \mathrm{~S}_{2}-\mathrm{L}-\mathrm{Cys}$ & $503 \pm 14$ & $193 \pm 6$ \\
$\mathrm{~K}-\mathrm{Mo}_{2} \mathrm{O}_{2} \mathrm{~S}_{2}-\mathrm{HNTA}$ & $499 \pm 147$ & $173 \pm 6$ \\
$\mathrm{~K}-\mathrm{Mo}_{2} \mathrm{O}_{2} \mathrm{~S}_{2}-$ EDTA & $515 \pm 6$ & $216 \pm 6$ \\
$\mathrm{Na}-\mathrm{Mo}_{2} \mathrm{O}_{4}-\mathrm{L}-\mathrm{Cys}$ & $502 \pm 14$ & $183 \pm 7$ \\
$\mathrm{~K}-\mathrm{Mo}_{2} \mathrm{O}_{4}-\mathrm{HNTA}$ & $526 \pm 43$ & Not soluble \\
$\mathrm{Na}-\mathrm{Mo}_{2} \mathrm{O}_{4}-\mathrm{EDTA}$ & $533 \pm 8$ & Not soluble \\
\hline
\end{tabular}

\subsection{Biological activities}

The solution studies evidence different behaviors in solution in the two series of coordination complexes prepared for this study. It was thus interesting to compare biological activities on different targets and associated either to 
alkali or to organic cations. The compounds were subjected to multiple in vitro biological tests to evaluate their antioxidant potential as well as their action on various cells and microorganisms as described in experimental section.

\subsubsection{Antitumoral properties}

One of the leading causes of cancer-related mortality is pancreatic cancer, while among women specifically it is the cervical cancer. Rhabdomyosarcoma is the most common soft tissue sarcoma affecting children and adolescents. Generally, these types of tumors are not detected at an early stage and are difficult to treat.[43-47] In this study, the in vitro tests were performed on three types of human cancer cell lines originating from these specific malignant organs, namely: HeLa (cervical cancer), BxPC-3 (human primary pancreatic adenocarcinoma), and $\mathrm{RD}$ (human rhabdomyosarcoma) in comparison with mammalian healthy cells (MDCK). The results, as $\mathrm{IC}_{50}$ values, are compiled in the Table 2 .

Table 2 Cytotoxicity of compounds on healthy (MDCK) cells, pancreatic cancer (BxPc-3), cervical cancer (HeLa) and rhabdomyosarcoma cancer (RD) cells. (NM = Not measured)

\begin{tabular}{|c|c|c|c|c|}
\hline Compound & $\begin{array}{c}\text { IC50 }(\mu M) \\
\text { MDCK }\end{array}$ & $\begin{array}{c}\text { IC }_{50}(\mu M) \\
\text { HeLa }\end{array}$ & $\begin{array}{c}\mathrm{IC}_{50}(\boldsymbol{\mu M}) \\
\text { BxPC-3 }\end{array}$ & $\begin{array}{c}\mathrm{IC}_{50}(\boldsymbol{\mu M}) \\
\mathrm{RD}\end{array}$ \\
\hline $\mathrm{Cs}_{1.5} \mathrm{Na}_{0.5}-\mathrm{Mo}_{2} \mathrm{O}_{2} \mathrm{~S}_{2}-\mathrm{Ox}$ & - & NM & - & - \\
\hline $\mathrm{K}-\mathrm{Mo}_{2} \mathrm{O}_{2} \mathrm{~S}_{2}$-L-cys & - & - & - & - \\
\hline TBA-Mo2 $\mathrm{O}_{2} \mathrm{~S}_{2}$-IDA & - & - & - & $172.8 \pm 1.6$ \\
\hline $\mathrm{K}-\mathrm{Mo}_{2} \mathrm{O}_{2} \mathrm{~S}_{2}$-HNTA & - & - & - & $\geq 100$ \\
\hline $\mathrm{K}-\mathrm{Mo}_{2} \mathrm{O}_{2} \mathrm{~S}_{2}$-EDTA & - & - & - & NM \\
\hline $\mathrm{PPh}_{4}-\mathrm{Mo}_{2} \mathrm{O}_{2} \mathrm{~S}_{2}$-EDTA & $\geq 100$ & $\geq 100$ & $59.81 \pm 26.45$ & NM \\
\hline $\mathrm{Mo}_{2} \mathrm{O}_{2} \mathrm{~S}_{2}$-L-his & - & - & - & NM \\
\hline $\mathrm{TBA}_{0.5} \mathrm{Na}_{1.5}-\mathrm{Mo}_{2} \mathrm{O}_{4}-\mathrm{Ox}$ & - & - & - & - \\
\hline $\mathrm{Na}-\mathrm{Mo}_{2} \mathrm{O}_{4}-\mathrm{L}-\mathrm{cys}$ & - & - & - & NM \\
\hline K-Mo2 $\mathrm{O}_{4}-\mathrm{HNTA}$ & - & - & - & NM \\
\hline 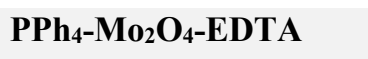 & $60.72 \pm 12.10$ & $\geq 100$ & $25.09 \pm 7.02$ & - \\
\hline $\mathrm{Na}_{4}-\mathrm{Mo}_{2} \mathrm{O}_{4}$-EDTA & - & - & - & - \\
\hline Li-Mo2 $\mathrm{O}_{4}$-EDTA & - & - & - & - \\
\hline DOXORUBICIN & $1.48 \pm 3.10$ & NM & $3.99 \pm 7.90$ & $1.31 \pm 4.90$ \\
\hline 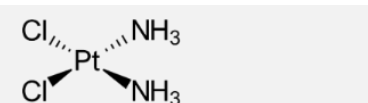 & $30.90 \pm 1.10$ & $3.99 \pm 0.33$ & $11.20 \pm 1.20$ & NM \\
\hline
\end{tabular}

Testing $\mathrm{Mo}_{2} \mathrm{O}_{2} \mathrm{~S}_{2}$ and $\mathrm{Mo}_{2} \mathrm{O}_{4}$ complexes with different ligands and in form of different salts serves as an indication of their toxicity on cells, and allows identification of the effect of each parameter i.e. cation, molybdenum core and ligand. The data in the table 2 show no toxicity or very weak toxicity in comparison to the reference cancer drugs Cis-platin and Doxorubicin. Only two complexes of EDTA show non-negligible values: $\mathbf{P P h} \mathbf{H}_{4}-\mathbf{M o}_{2} \mathbf{O}_{2} \mathbf{S}_{2}-$ EDTA has $\mathrm{IC}_{50}=59.81 \pm 26.45 \mu \mathrm{M}$ on BxPc-3 cancer cells and $\mathbf{P P h}_{4}-\mathbf{M o}_{2} \mathbf{O}_{4}$-EDTA has $\mathrm{IC}_{50}=25.09 \pm 7.02 \mu \mathrm{M}$ on BxPc-3 cancer cells and $60.72 \pm 12.1 \mu \mathrm{M}$ on normal MDCK cells, which means that all other complexes are non-toxic or almost non-toxic. The comparison of these two complexes in their alkali salts which are not at all toxic suggests that it is not the $\left[\mathrm{Mo}_{2} \mathrm{O}_{4}(\mathrm{EDTA})\right]^{2-}$ and $\left[\mathrm{Mo}_{2} \mathrm{O}_{2} \mathrm{~S}_{2}(\text { EDTA) }]^{2-}\right.$ complexes that induces toxicity for these two compounds but the tetraphenylphosphonium counter-cations. [48] Hence, $\mathrm{Mo}_{2} \mathrm{O}_{2} \mathrm{~S}_{2}$ and $\mathrm{Mo}_{2} \mathrm{O}_{4}$ complexes with Histidine, Cysteine, IDA, HNTA and EDTA ligands are surely safe in vitro as long as the cation is alkaline. These findings reveal the importance of the counter cation on the overall toxicity and show that molybdenum $(\mathrm{V})\left[\mathrm{Mo}_{2} \mathrm{O}_{2} \mathrm{~S}_{2}\right]^{2+}$ and $\left[\mathrm{Mo}_{2} \mathrm{O}_{4}\right]^{2+}$ moieties coordinated with biocompatible ligands are non-toxic. This 
is in good agreement with other cytotoxicity results related to $\mathrm{Mo}_{2} \mathrm{O}_{2} \mathrm{~S}_{2}$-based complexes associated to $\mathrm{NEt}_{4}{ }^{+}$or alkali cations reported in the literature.[24]

\subsubsection{Antioxidative properties}

The $\left[\mathrm{Mo}^{(\mathrm{V})}{ }_{2} \mathrm{O}_{2} \mathrm{E}_{2}\right]^{2+}$ compounds have served for many years as small molecular models for the active centers of many molybdoenzymes.[12,20,35,49-56] Such molybdenum-sulfur bridged systems are indeed involved in certain enzymatic electron transfer processes and therefore an antioxidant activity can be expected. Here we have tested the possibility of such biological application by measuring the radical scavenging capacity against two common oxidant radicals: $\mathrm{ABTS}^{\cdot+}$ and $\mathrm{DDPH}^{\bullet}$. In the first method, $\mathrm{ABTS}^{\cdot+}$ radical cation is inhibited by reduction in a one electron transfer process, whereas the second method supposes neutralization of DDPH ${ }^{\bullet}$ by a hydrogendonating antioxidant. This will provide additional clues regarding the mechanism behind the in vitro antiradical property of our complexes. The $\mathrm{IC}_{50}$ values are given in Table 3.

Table 3 Antioxidant activities for $\mathrm{Mo}_{2} \mathrm{O}_{2} \mathrm{~S}_{2}$ and $\mathrm{Mo}_{2} \mathrm{O}_{4}$ complexes against ABTS and DPPH

\begin{tabular}{|c|c|c|}
\hline Compound & $\begin{array}{c}\text { IC }_{50}(\boldsymbol{\mu M}) \\
\text { ABTS }\end{array}$ & $\begin{array}{c}\mathrm{IC}_{50}(\boldsymbol{\mu M}) \\
\text { DPPH }\end{array}$ \\
\hline $\mathrm{Cs}_{1.5} \mathrm{Na}_{0.5}-\mathrm{Mo}_{2} \mathrm{O}_{2} \mathrm{~S}_{2}-\mathrm{Ox}$ & $42.5 \pm 7.10$ & $\geq 100$ \\
\hline $\mathrm{K}-\mathrm{Mo}_{2} \mathrm{O}_{2} \mathrm{~S}_{2}$-L-cys & $1.9 \pm 0.12$ & $36.4 \pm 6.10$ \\
\hline TBA-Mo2 $\mathrm{O}_{2} \mathrm{~S}_{2}-\mathrm{IDA}$ & $27.2 \pm 3.69$ & - \\
\hline $\mathrm{K}-\mathrm{Mo}_{2} \mathrm{O}_{2} \mathrm{~S}_{2}-\mathrm{HNTA}$ & $20.1 \pm 0.25$ & - \\
\hline $\mathrm{K}-\mathrm{Mo}_{2} \mathrm{O}_{2} \mathrm{~S}_{2}$-EDTA & - & - \\
\hline $\mathrm{PPh}_{4}-\mathrm{Mo}_{2} \mathrm{O}_{2} \mathrm{~S}_{2}$-EDTA & - & - \\
\hline $\mathrm{Mo}_{2} \mathrm{O}_{2} \mathrm{~S}_{2}$-L-his & $7.0 \pm 0.52$ & - \\
\hline $\mathrm{TBA}_{0.5} \mathrm{Na}_{1.5}-\mathrm{Mo}_{2} \mathrm{O}_{4}-\mathrm{Ox}$ & $74.9 \pm 3.78$ & $\geq 100$ \\
\hline $\mathrm{Na}-\mathrm{Mo}_{2} \mathrm{O}_{4}-\mathrm{L}-\mathrm{cys}$ & $2.73 \pm 0.65$ & - \\
\hline K-Mo2 $\mathrm{O}_{4}$-HNTA & - & - \\
\hline $\mathrm{PPh}_{4}-\mathrm{Mo}_{2} \mathrm{O}_{4}$-EDTA & - & - \\
\hline Na-Mo2 $\mathrm{O}_{4}-E D T A$ & - & - \\
\hline $\mathrm{Li}-\mathrm{Mo}_{2} \mathrm{O}_{4}$-EDTA & - & - \\
\hline TROLOX & $26.3 \pm 0.70$ & $48.9 \pm 0.80$ \\
\hline RUTIN & $20.7 \pm 0.12$ & $64.8 \pm 2.10$ \\
\hline
\end{tabular}

$\mathrm{NM}=$ Not measured

Out of the 13 measured compounds, 7 of them show a significant antioxidant activity. The table 3 indicates better results in the case of ABTS method, suggesting the appropriate electron transfer mechanism or the slow reaction kinetics with $\mathrm{DDPH}^{*}$ (incubation time dependent activity). Clearly the compounds bearing cysteine ligands are the most powerful antioxidants of the series, being more active than reference antioxidant Trolox (water soluble analogue of Vitamin E) (K-Mo2 $\mathbf{O}_{2} \mathbf{S}_{2}-\mathbf{C y s}$ almost 14 times and $\mathbf{N a - M o 2} \mathbf{O}_{4}-\mathbf{C y s}$ almost 10 times respectively) and even the natural flavonoid Rutin $\left(\mathbf{K}-\mathbf{M o}_{2} \mathbf{O}_{2} \mathbf{S}_{2}-\mathbf{C y s}\right.$ almost 11 times and $\mathbf{N a - M o} \mathbf{O}_{4}-\mathbf{C y s}$ almost 8 times respectively). Somehow, cysteine ligands help in this process. Indeed, cysteine molecule is known to have antioxidant properties due to oxidizable thiol - $\mathrm{SH}$ group, which becomes more reactive in ionized thiolate form and has the ability to form disulfide bonds, like in the oxidative dimerization of cysteine into cystine.[57,58] Oxalate and Histidine are also known to be able to be oxidized and the activities of the corresponding complexes are also probably related to the activity of the ligands.

In contrast, IDA, NTA or EDTA ligands are not expected to be oxidized. The chelate-type $\left[\mathbf{M o}_{2} \mathbf{O}_{2} \mathbf{E}_{2}(\mathbf{E D T A})\right]^{2-}$ complexes have no activity at all as for the other coordination complexes formed around the $\mathrm{Mo}_{2} \mathrm{O}_{4}$ core, while the $\mathrm{Mo}_{2} \mathrm{O}_{2} \mathrm{~S}_{2}$ complexes formed with IDA and HNTA display some activity. It suggests that his antioxidant ability depends on the redox properties of the $\mathrm{Mo}(\mathrm{V})$ centers which can be tuned with the nature of the coordinated ligand and by its oxo or sulfurated environment and more importantly from the ligand's redox properties itself.[20,21,53,59] The stability of the EDTA could also play a role by protecting the Mo(V) centers from oxidation, a process which leads to the breaking of the Mo-Mo bond and possibly to the decomposition of the compound,[60] while coordination of two separate ligands on each side of the $\mathrm{Mo}_{2} \mathrm{O}_{2} \mathrm{E}_{2}$ core leads to more labile 
structures and with higher ability to be oxidized. The combination of the aforementioned factors made $\mathrm{K}_{2}\left[\mathrm{Mo}_{2} \mathrm{O}_{2} \mathrm{~S}_{2}(\mathrm{~L} \text {-cys) })_{2}\right] .5 \mathrm{H}_{2} \mathrm{O}$ and $\mathbf{N a}_{2}\left[\mathrm{Mo}_{2} \mathrm{O}_{4}(\mathrm{~L}-\mathrm{cys})_{2}\right] .5 \mathrm{H}_{2} \mathrm{O}$ to act as good small molecular-weight nonenzymatic antioxidants.

\subsubsection{Antibacterial and antifungal activities}

In the context of the worrying rise of antibiotic resistance levels worldwide, treating common infectious diseases requires unceasing demand for new drugs combining efficiency and safety. Here, our molybdenum complexes were tested for their action deliberately on bacterial and fungal strains with medium to high antibiotic resistance. As clearly seen from the results in the tables 4 and 5 below, the majority of complexes have a weak antibacterial and antifungal activity against all tested G+ and G- bacteria and fungi, except for two of them. $\mathbf{P P h} \mathbf{P}_{4}-\mathbf{M o}_{2} \mathbf{O}_{2} \mathbf{S}_{2}-$ EDTA and $\mathbf{P P h}_{4}-\mathrm{Mo}_{2} \mathrm{O}_{4}$-EDTA are indeed significantly active against Gram positive bacteria with minimum inhibitory concentrations (MIC) of $0.002 \mathrm{mg} / \mathrm{mL}$ (S. aureus, B. cereus), $0.004 \mathrm{mg} / \mathrm{mL}$ (B. subtilis) and respectively $0.004 \mathrm{mg} / \mathrm{mL}$ (S. aureus, B. cereus), 0.008 (B. subtilis), being twice as active as the reference antibiotic Doxycycline or even pretty active when Doxycycline has no activity at all.

Against fungi our compounds have barely any effect. Only those with tetraphenylphosphonium $\left(\mathbf{P P h}_{4}-\mathbf{M o}_{2} \mathbf{O}_{2} \mathbf{S}_{2}-\right.$ EDTA, $\mathbf{P P h}_{4}-\mathrm{Mo}_{2} \mathrm{O}_{4}$-EDTA) have a better activity, but still $\sim 15$ times less active than Fluconazole fungi inhibitor drug.

Structure-activity correlation shows an activity dependency on the nature of the cation associated to the coordination compounds. Apparently $\mathrm{PPh}_{4}{ }^{+}$cation is responsible for this inhibitory effect on bacteria and fungi, since other salts of the same complexes do not show any significant activities. This seems logical since tetraphenylphosphonium - a lipophilic membrane-permeable cation is considered biocide, acting upon several cellular targets inside microorganisms.[48] It is actually an excellent strategy to obtain multi-target compounds by combining bioactive organic cations to our bioactive coordination complexes. One inspiring example is the association of antibacterial tetraalkylammonium cations with $\left[\alpha-\mathrm{SiW}_{11} \mathrm{O}_{39}\right]^{8-}$ to create POM-based ionic liquids as coatings with anticorrosion and antimicrobial properties.[61]

Table 4 Activity of $\mathrm{Mo}_{2} \mathrm{O}_{2} E_{2}$ complexes against $G+$ and $G$ - bacteria

Gram positive Gram negative

\begin{tabular}{|c|c|c|c|c|c|}
\hline Compound & $\begin{array}{c}\text { MIC }(\mathrm{mg} / \mathrm{ml}) \\
\text { Staphylococcus } \\
\text { aureus } \\
\text { ATCC } 25923\end{array}$ & $\begin{array}{c}\text { MIC }(\mathrm{mg} / \mathrm{ml}) \\
\text { Bacillus cereus } \\
\text { ATCC } 11778\end{array}$ & $\begin{array}{c}\text { MIC (mg/ml) } \\
\text { Bacillus subtilis } \\
\text { ATCC } 6633\end{array}$ & $\begin{array}{c}\text { MIC } \\
(\mathrm{mg} / \mathrm{ml}) \\
\text { Escherichia } \\
\text { coli } \\
\text { ATCC } \\
25922\end{array}$ & $\begin{array}{c}\text { MIC }(\mathrm{mg} / \mathrm{ml}) \\
\text { Acinetobacter } \\
\text { baumannii } \\
\text { ATCC BAA- } \\
747\end{array}$ \\
\hline $\mathrm{K}-\mathrm{Mo}_{2} \mathrm{O}_{2} \mathrm{~S}_{2}-\mathrm{L}-\mathrm{Cys}$ & 0.2500 & 0.2500 & 0.2500 & - & - \\
\hline $\mathrm{Mo}_{2} \mathrm{O}_{2} \mathrm{~S}_{2}$-L-His & 0.2500 & - & - & - & - \\
\hline TBA-Mo $-\mathrm{Mo}_{2} \mathrm{O}_{2} \mathrm{~S}_{2}$-IDA & - & - & - & - & - \\
\hline $\mathrm{K}-\mathrm{Mo}_{2} \mathrm{O}_{2} \mathrm{~S}_{2}$-HNTA & 0.2500 & 0.2500 & 0.2500 & 0.5000 & 0.2500 \\
\hline K-Mo $\mathrm{O}_{2} \mathrm{O}_{2} \mathrm{~S}_{2}$-EDTA & 0.0625 & 0.2500 & 0.5000 & 0.2500 & 0.1250 \\
\hline $\mathrm{PPh}_{4}-\mathrm{Mo}_{2} \mathrm{O}_{2} \mathrm{~S}_{2}$-EDTA & 0.0019 & 0.0019 & 0.0039 & 0.1250 & 0.5000 \\
\hline $\mathrm{Na}-\mathrm{Mo}_{2} \mathrm{O}_{4}-\mathrm{L}-\mathrm{Cys}$ & - & - & - & - & - \\
\hline $\mathrm{K}-\mathrm{Mo}_{2} \mathrm{O}_{4}$-HNTA & 0.5000 & 0.5000 & 0.5000 & - & - \\
\hline $\mathrm{Na}-\mathrm{Mo}_{2} \mathrm{O}_{4}$-EDTA & - & - & - & - & - \\
\hline $\mathrm{Li}-\mathrm{Mo}_{2} \mathrm{O}_{4}$-EDTA & 0.2500 & - & 0.2500 & - & - \\
\hline $\mathrm{PPh}_{4}-\mathrm{Mo}_{2} \mathrm{O}_{4}$-EDTA & 0.0039 & 0.0039 & 0.0078 & 0.1250 & 0.2500 \\
\hline Doxycycline & 0.0040 & - & - & 0.0320 & - \\
\hline
\end{tabular}


Table 5 Activity of $\mathrm{Mo}_{2} \mathrm{O}_{2} \mathrm{E}_{2}$ complexes against fungi

\begin{tabular}{|c|c|c|c|}
\hline Compound & $\begin{array}{c}\text { MIC (mg/ml) } \\
\text { Candida albicans } \\
\text { ATCC } 10231\end{array}$ & $\begin{array}{c}\text { MIC (mg/ml) } \\
\text { Candida krusei/parapsilosis } \\
\text { ATCC } 6258 / 22019\end{array}$ & $\begin{array}{c}\text { MIC (mg/ml) } \\
\text { Cryptococcus } \\
\text { neoformans } \\
\text { CECT } 1043\end{array}$ \\
\hline $\mathrm{K}-\mathrm{Mo}_{2} \mathrm{O}_{2} \mathrm{~S}_{2}-\mathrm{L}-\mathrm{Cys}$ & - & - & - \\
\hline $\mathrm{Mo}_{2} \mathrm{O}_{2} \mathrm{~S}_{2}$-L-His & 0.5000 & 0.2500 & 0.5000 \\
\hline TBA-Mo2 $\mathrm{O}_{2} \mathrm{~S}_{2}$-IDA & - & - & - \\
\hline $\mathrm{K}-\mathrm{Mo}_{2} \mathrm{O}_{2} \mathrm{~S}_{2}$-HNTA & 0.5000 & 0.5000 & 0.2500 \\
\hline $\mathrm{K}-\mathrm{Mo}_{2} \mathrm{O}_{2} \mathrm{~S}_{2}$-EDTA & 0.1250 & 0.0625 & 0.0156 \\
\hline $\mathrm{PPh}_{4}-\mathrm{Mo}_{2} \mathrm{O}_{2} \mathrm{~S}_{2}$-EDTA & 0.0312 & 0.0312 & 0.0039 \\
\hline $\mathrm{Na}-\mathrm{Mo}_{2} \mathrm{O}_{4}-\mathrm{L}-\mathrm{Cys}$ & - & - & - \\
\hline K-Mo2 $\mathrm{O}_{4}-\mathrm{HNTA}$ & - & - & - \\
\hline $\mathrm{Na}-\mathrm{Mo}_{2} \mathrm{O}_{4}-\mathrm{EDTA}$ & - & - & - \\
\hline Li-Mo $\mathbf{M}_{2} \mathrm{O}_{4}$-EDTA & - & - & - \\
\hline 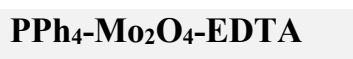 & 0.0312 & 0.0625 & 0.0039 \\
\hline Fluconazole & 0.0020 & 0.0020 & 0.0016 \\
\hline
\end{tabular}

\subsubsection{Influence on unicellular microorganisms}

Toxicity bioassay using infusoria microorganisms is a simple and very effective method to investigate the effect of chemical compounds on living organisms. Paramecia are aquatic single-celled eukaryotes, called protozoans, having short life cycle and rapid population growth through asexual reproduction. Their behavior and development are strongly dependent on the quality parameters of the environment, therefore they serve as good bioindicators for toxicological studies in laboratory conditions.[62-66] Here, we test the toxicity of our compounds by exposing Paramecia caudatum Ehrenberg to different concentrations of each abiotic factor (chemical stressor) and the median lethal concentration $\left(\mathrm{LC}_{50}\right)$ is evaluated based on their viability results.

Table 6 Toxicity of $\mathrm{Mo}_{2} \mathrm{O}_{2} \mathrm{E}_{2}$ complexes on Paramecia

\begin{tabular}{|c|c|c|}
\hline \multirow{2}{*}{ Compound } & \multicolumn{2}{|c|}{$\mathrm{LC}_{50}(\boldsymbol{\mu M})$} \\
\hline & $24 \mathrm{~h}$ & $48 \mathrm{~h}$ \\
\hline $\mathrm{K}-\mathrm{Mo}_{2} \mathrm{O}_{2} \mathrm{~S}_{2}-\mathrm{L}-\mathrm{Cys}$ & $\geq 100$ & $\geq 100$ \\
\hline $\mathrm{Mo}_{2} \mathrm{O}_{2} \mathrm{~S}_{2}$-L-His & $28.72 \pm 5.5$ & $\geq 100$ \\
\hline TBA-Mo ${ }_{2} \mathrm{O}_{2} \mathrm{~S}_{2}$-IDA & $56.98 \pm 5.6$ & $48.66 \pm 2.2$ \\
\hline $\mathrm{K}-\mathrm{Mo}_{2} \mathrm{O}_{2} \mathrm{~S}_{2}$-HNTA & $\geq 100$ & $\geq 100$ \\
\hline $\mathrm{K}-\mathrm{Mo}_{2} \mathrm{O}_{2} \mathrm{~S}_{2}$-EDTA & $\geq 100$ & $\geq 100$ \\
\hline $\mathrm{PPh}_{4}-\mathrm{Mo}_{2} \mathrm{O}_{2} \mathrm{~S}_{2}$-EDTA & $40.25 \pm 2.6$ & $\geq 100$ \\
\hline $\mathrm{Na}-\mathrm{Mo}_{2} \mathrm{O}_{4}-\mathrm{L}-\mathrm{Cys}$ & $\geq 100$ & $\geq 100$ \\
\hline K-Mo $\mathrm{O}_{2} \mathrm{O}_{4}-\mathrm{HNTA}$ & $3.3 \pm 0.2$ & $1.7 \pm 0.01$ \\
\hline $\mathrm{Na}-\mathrm{Mo}_{2} \mathrm{O}_{4}$-EDTA & $\geq 100$ & $\geq 100$ \\
\hline
\end{tabular}




\begin{tabular}{|l|ll|}
\hline Li-Mon $\mathbf{O}_{4}$-EDTA & $\geq 100$ & $\geq 100$ \\
\hline PPh $_{4}-\mathrm{Mo}_{2} \mathbf{O}_{4}$-EDTA & $\geq 100$ & $\geq 100$ \\
\hline
\end{tabular}

The majority of compounds are non-toxic since they have $\mathrm{LC}_{50} \geq 100 \mu \mathrm{M}$. Once again, the non-natural cations $\mathrm{TBA}^{+}$and $\mathrm{PPh}_{4}^{+}$salts show inhibition action against microorganisms, as exposed anteriorly on bacteria and fungi, especially when associated to the $\mathrm{Mo}_{2} \mathrm{O}_{2} \mathrm{~S}_{2}{ }^{2+}$ core. The K-Mo $\mathbf{O}_{4}-\mathrm{O} N \mathrm{H} A$ substance was identified as the most toxic, killing half of the paramecia at very low concentrations ( $3.3 \mu \mathrm{M}$ after $24 \mathrm{~h}$ or $1.7 \mu \mathrm{M}$ after $48 \mathrm{~h}$ ). Thereby, most of the compounds of this class prove to be generally inoffensive to model unicellular systems and could eventually qualify for biological tests on superior organisms.

\subsubsection{Growth-stimulating properties}

Spirulina platensis is a multicellular and filamentous blue-green microalga that draw considerable attention as a source of bioactive substances like proteins, vitamins, essential amino acids, $\beta$-carotene, etc. and has a great potential for development, especially as a small-scale crop for nutritional enhancement in humans and animals and as drugs. [67,68] Research in recent decades have shown that the use of inorganic salts as well as coordination compounds of $\mathrm{Zn}(\mathrm{II}), \mathrm{Fe}(\mathrm{III}), \mathrm{Cr}(\mathrm{III}), \mathrm{Cu}(\mathrm{II})$ and other transition metals as chemical regulators contributes to the increased synthesis of bioactive components in the cyanobacterium Spirulina platensis, as well as to the biotransformation of the elements by their incorporation into bioorganic components.[69] The use of chemical regulators in phycobiotechnology has resulted in the development of a series of procedures to increase the productivity of Spirulina and to trigger the biosynthesis of specific metabolites of the biomass, including bioaccumulation of elements.[70]

Investigation of $\mathrm{Mo}_{2} \mathrm{O}_{2} \mathrm{E}_{2}$ compounds as new chemical regulators containing a molybdenum source for cultivation of Spirulina platensis could present interest, given the important role of this oligoelement in the metabolism of prokaryotic and eukaryotic organisms. Therefore, their effect on this microalga's productivity and biochemical composition is examined hereafter. The results are given in table 6 .

This study was focused on the three compounds K-Mo2 $\mathbf{O}_{2} \mathbf{S}_{2}-\mathbf{H N T A}$, TBA-Mon $\mathbf{O}_{2} \mathbf{S}_{2}-\mathrm{IDA}$ and $\mathbf{P P h}_{4}-\mathrm{Mo}_{2} \mathbf{O}_{4}-$ EDTA. As seen in table 6, the results do not manifest any toxic effect towards Spirulina in the investigated concentration ranges. Productivity tends to rise proportionally with concentration in the case of $\mathbf{K}-\mathbf{M o} \mathbf{O}_{2} \mathbf{O}_{2} \mathbf{S}_{2}-$ HNTA, TBA-Mo $\mathbf{O}_{2} \mathbf{O}_{2} \mathbf{S}_{2}$-IDA, reaching maximum values at $50 \mathrm{mg} / \mathrm{L}$. For $\mathbf{K}-\mathrm{Mo}_{2} \mathbf{O}_{2} \mathbf{S}_{2}-\mathbf{H N T A}$ we get the higher growth rate of $+6.94 \%$, which equals to $1.26 \mathrm{~g} / \mathrm{L}$ in the $10^{\text {th }}$ day. Beyond $50 \mathrm{mg} / \mathrm{L}$ concentration, a minor decrease is observed, but the productivity is still comparable to the reference sample. The repartition of biochemical components of spirulina seems to be reshaped also. The protein quantity is diminished by $3.1 \%$ for the HNTAbearing compound while in the presence of TBA-Mo2 $\mathbf{O}_{2} \mathbf{S}_{2}$-IDA it increased by $8.5 \%$. The biomass' peptide content, separated from the total protein fraction increases within the following concentration limits: $40-70 \mathrm{mg} / \mathrm{L}$ (K-Mo $\mathbf{O}_{2} \mathbf{S}_{2}$-HNTA) and 50-70 mg/L (TBA-Mo $\mathbf{O}_{2} \mathbf{O}_{2} \mathbf{S}_{2}$-IDA), reaching values that exceed the reference by 11.04$29.22 \%, 34.09-77.92 \%$ and $16.23-87.01 \%$, respectively. Concerning the two compounds containing the $\mathbf{M o}_{2} \mathbf{O}_{2} \mathbf{S}_{2}$ core, the gain in carbohydrates and lipids goes up to $19.63 \%$ and $14.04 \%$ for the one with HNTA ligands, whereas 9.56\% and $23.71 \%$ for the one with IDA ligands. At first look, $\mathbf{P P h} \mathbf{P h}_{4}-\mathbf{M o}_{2} \mathbf{O}_{4}$-EDTA seems unsuitable for spirulina growing as productivity tends to decrease by $17.7 \%$ in the presence of $10 \mathrm{mg} / \mathrm{L}$ of this compound. However, this compound shows excellent results in selectively boosting the peptide ratio to $222.7 \%$. So, despite the $1 / 6$ biomass loss, production of peptide-rich spirulina is an interesting feature.

Table 6 Activity of $\mathrm{Mo}_{2} \mathrm{O}_{2} E_{2}$ complexes on Spirulina platensis growth

\begin{tabular}{|c|c|c|c|c|c|c|c|c|c|c|}
\hline \multirow[t]{2}{*}{ Compound } & \multirow{2}{*}{$\begin{array}{c}\text { Conc., } \\
\text { mg/L }\end{array}$} & \multirow{2}{*}{$\begin{array}{l}\text { Producti } \\
\text { vity* in } \\
\text { the } 10^{\text {th }} \\
\text { day, } g / L\end{array}$} & \multicolumn{2}{|c|}{ Proteins* } & \multicolumn{2}{|c|}{ Peptides* } & \multicolumn{2}{|c|}{ Carbohydrates* } & \multicolumn{2}{|c|}{ Lipids* } \\
\hline & & & $\begin{array}{c}\text { \% of } \\
\text { dry } \\
\text { weight }\end{array}$ & $\begin{array}{c}\% \\
\text { compared } \\
\text { to } \\
\text { reference }\end{array}$ & $\begin{array}{c}\text { \% of } \\
\text { dry } \\
\text { weight }\end{array}$ & $\begin{array}{c}\% \\
\text { compared } \\
\text { to } \\
\text { reference }\end{array}$ & $\begin{array}{c}\text { \% of } \\
\text { dry } \\
\text { weight }\end{array}$ & $\begin{array}{c}\% \\
\text { compared } \\
\text { to } \\
\text { reference } \\
\end{array}$ & $\begin{array}{c}\text { \% of } \\
\text { dry } \\
\text { weight }\end{array}$ & $\begin{array}{c}\% \\
\text { compared } \\
\text { to } \\
\text { reference }\end{array}$ \\
\hline Control & 0 & 1,180 & 65,95 & 100,00 & 3,08 & 100,00 & 11,61 & 100,00 & 10,33 & 100,00 \\
\hline
\end{tabular}




\begin{tabular}{|c|c|c|c|c|c|c|c|c|c|c|}
\hline $\begin{array}{c}\mathrm{K}- \\
\mathrm{Mo}_{2} \mathrm{O}_{2} \mathrm{~S}_{2-} \\
\text { HNTA }\end{array}$ & $\begin{array}{l}20 \\
30 \\
40 \\
50 \\
60 \\
70\end{array}$ & $\begin{array}{l}1,191 \\
1,211 \\
1,240 \\
1,261 \\
1,255 \\
1,183\end{array}$ & $\begin{array}{l}67,50 \\
65,50 \\
64,39 \\
64,76 \\
64,46 \\
63,91\end{array}$ & $\begin{array}{c}102,35 \\
99,32 \\
97,63 \\
98,19 \\
97,74 \\
96,90\end{array}$ & $\begin{array}{l}2,98 \\
3,02 \\
4,13 \\
4,16 \\
5,49 \\
5,48\end{array}$ & $\begin{array}{c}96,75 \\
98,05 \\
134,09 \\
135,06 \\
178,25 \\
177,92\end{array}$ & $\begin{array}{l}12,29 \\
12,53 \\
12,78 \\
13,89 \\
13,59 \\
11,13\end{array}$ & $\begin{array}{c}105,86 \\
107,92 \\
110,08 \\
119,63 \\
117,05 \\
95,87\end{array}$ & $\begin{array}{l}11,32 \\
11,56 \\
11,57 \\
11,22 \\
11,78 \\
11,24\end{array}$ & $\begin{array}{l}109,58 \\
111,91 \\
112,00 \\
108,62 \\
114,04 \\
108,81\end{array}$ \\
\hline $\begin{array}{c}\text { TBA- } \\
\mathrm{Mo}_{2} \mathrm{O}_{2} \mathrm{~S}_{2-} \\
\text { IDA }\end{array}$ & $\begin{array}{l}20 \\
30 \\
40 \\
50 \\
60 \\
70\end{array}$ & $\begin{array}{l}1,122 \\
1,173 \\
1,206 \\
1,221 \\
1,218 \\
1,179\end{array}$ & $\begin{array}{l}71,56 \\
70,22 \\
66,33 \\
67,90 \\
63,86 \\
61,99\end{array}$ & $\begin{array}{c}108,51 \\
106,48 \\
100,58 \\
102,96 \\
96,82 \\
94,00\end{array}$ & $\begin{array}{l}3,16 \\
3,14 \\
3,16 \\
3,58 \\
5,74 \\
5,76\end{array}$ & $\begin{array}{l}102,60 \\
101,95 \\
102,60 \\
116,23 \\
186,36 \\
187,01\end{array}$ & $\begin{array}{l}11,92 \\
11,94 \\
11,96 \\
12,15 \\
12,43 \\
12,72\end{array}$ & $\begin{array}{l}102,80 \\
102,88 \\
102,99 \\
104,65 \\
107,06 \\
109,56\end{array}$ & $\begin{array}{l}11,12 \\
11,17 \\
11,91 \\
12,51 \\
12,13 \\
12,78\end{array}$ & $\begin{array}{l}107,65 \\
108,13 \\
115,29 \\
121,10 \\
117,42 \\
123,71\end{array}$ \\
\hline $\begin{array}{c}\mathrm{PPh}_{4-} \\
\mathrm{Mo}_{2} \mathrm{O}_{4-} \\
\text { EDTA }\end{array}$ & $\begin{array}{c}5 \\
10\end{array}$ & $\begin{array}{l}1,126 \\
0,971\end{array}$ & $\begin{array}{l}63,46 \\
62,79\end{array}$ & $\begin{array}{l}96,22 \\
95,21\end{array}$ & $\begin{array}{l}6,87 \\
6,86\end{array}$ & $\begin{array}{l}223,05 \\
222,73\end{array}$ & $\begin{array}{l}11,40 \\
11,24\end{array}$ & $\begin{array}{l}98,19 \\
96,82\end{array}$ & $\begin{array}{l}10,37 \\
10,55\end{array}$ & $\begin{array}{l}100,38 \\
102,17\end{array}$ \\
\hline
\end{tabular}

\section{Experimental section}

Experimental details are given in Electronic Supporting Information.

\section{Conclusion}

In this paper, we have investigated two series of dinuclear complexes based on $\left[\mathrm{Mo}_{2} \mathrm{O}_{2} \mathrm{~S}_{2}\right]^{2+}$ and $\left[\mathrm{Mo}_{2} \mathrm{O}_{4}\right]^{2+}$ cores. Almost all of them have been obtained in a one-step synthesis in water, consistent with green chemistry principles and a new synthetic procedure has been applied for sulfurated ones.

The solution studies revealed totally different behaviors for both series of complexes in terms of dynamics and lability depending on the nature of the central core and of the ligand. Although, the major part of these complexes was already known in the literature as models for enzymes, the biological activities of such series of complexes was in fact poorly explored. In the present study, strong evidences have been acquired for the biological efficiency of these coordination compounds. Although some compounds display cytotoxicity, we have evidenced that it is probably due to the organic counter cations $\mathrm{PPh}_{4}{ }^{+}$, which are non-innocent. Therefore, we can say that these molybdenum complexes appear non-toxic.

Complexes $\left[\mathrm{Mo}_{2} \mathrm{O}_{2} \mathbf{E}_{2} \text { (EDTA) }\right]^{2-}$ associating $\mathrm{PPh}_{4}{ }^{+}$cations have been found with significant activity against all tested Gram-positive bacteria Staphylococcus aureus, Bacillus cereus and Bacillus subtilis with as low as 1.9 $\mu \mathrm{g} / \mathrm{mL}$ of compound and also against all tested fungi Candida albicans, Candida krusei/parapsilosis and Cryptococcus neoformans with as low as $3.9 \mu \mathrm{g} / \mathrm{mL}$ of compound due to the antimicrobial effect of the cation. Such compounds can be considered as simple but relatively potent bacterial and fungal inhibitors. The majority of compounds are harmless in vitro and seem promising for application in biology as antioxidant agents, with minimal $\mathrm{IC}_{50} 1.9 \mu \mathrm{M}$.

At the same time, the first three tested Mo complexes of our series are able to promote growth of Spirulina platensis culture, building up to $7 \%$ more biomass and they modulate its biochemical composition, diversifying even more its possible uses to a food supplement with rich peptide content (+123\%) for instance. Concerning this class of complexes, novel biological tests are envisioned to eventually extend the arsenal of beneficial properties to other possible applications.

\section{Acknowledgements}

SF gratefully acknowledges Mrs. Aurelie Avenel for her contribution for the syntheses of complexes, Dr Nathalie Leclerc for ATG and EDX measurements and Dr Clément Falaise for his help for X-ray diffraction studies. This work has been supported by a public grant overseen by the French National Research Agency (ANR) under the contract POMEAH•ANR-08-JCJC-0097 and the LABEX CHARMMMAT ANR - 11-LABX-0039 (Project COMPA). We also thank University of Versailles, the "Institut Universitaire de France, IUF" and the CNRS for financial support. AF and DC gratefully acknowledge Campus France for Eiffel Doctorate grant as well as IUF and State University of Moldova.

\section{Supporting Information}

The Supporting Information contains, experimental details followed for syntheses, characterizations (FT-IR and ESI-MS spectra) and protocols for biological tests. It contains also, additional NMR spectra 


\section{References}

[1] L.B. Maia, I. Moura, J.J.G. Moura, in: Molybdenum Tungsten Enzym., RSC, 2016: pp. 1-80. https://doi.org/10.1039/9781782623915-00001.

[2] R. Hille, Trends Biochem. Sci. 27 (2002) 360-367. https://doi.org/10.1016/S09680004(02)02107-2.

[3] R.J.P. Williams, J.J.R. Fraústo da Silva, Biochem. Biophys. Res. Commun. 292 (2002) 293-299. https://doi.org/10.1006/bbrc.2002.6518.

[4] R. Hille, R. Mendel, Coord. Chem. Rev. 255 (2011) 991-992. https://doi.org/10.1016/j.ccr.2010.10.014.

[5] L.C. Seefeldt, D.R. Dean, B.M. Hoffman, in: Molybdenum Tungsten Enzym., RSC, 2016: pp. 274296. https://doi.org/10.1039/9781782623915-00274.

[6] U. Kappler, G. Schwarz, in: Molybdenum Tungsten Enzym., 2016: pp. 240-273. https://doi.org/10.1039/9781782623915-00240.

[7] T. Nishino, K. Okamoto, S. Leimkühler, in: Molybdenum Tungsten Enzym., 2016: pp. 192-239. https://doi.org/10.1039/9781782623915-00192.

[8] R. Hille, T. Nishino, F. Bittner, Coord. Chem. Rev. 255 (2011) 1179-1205. https://doi.org/10.1016/j.ccr.2010.11.034.

[9] D. Coucouvanis, P.E. Mosier, K.D. Demadis, S. Patton, S.M. Malinak, C.G. Kim, M.A. Tyson, J. Am. Chem. Soc. 115 (1993) 12193-12194. https://doi.org/10.1021/ja00078a079.

[10] D. Coucouvanis, E.D. Simhon, D. Swenson, N.C. Baenziger, J. Chem. Soc. Chem. Commun. 0 (1979) 361-362. https://doi.org/10.1039/C39790000361.

[11] E.D. Simhon, N.C. Baenziger, M. Kanatzidis, M. Draganjac, D. Coucouvanis, J. Am. Chem. Soc. 103 (1981) 1218-1219. https://doi.org/10.1021/ja00395a040.

[12] D. Coucouvanis, A. Toupadakis, J.D. Lane, S.M. Koo, C.G. Kim, A. Hadjikyriacou, J. Am. Chem. Soc. 113 (1991) 5271-5282. https://doi.org/10.1021/ja00014a021.

[13] D. Coucouvanis, K.D. Demadis, C.G. Kim, R.W. Dunham, J.W. Kampf, J. Am. Chem. Soc. 115 (1993) 3344-3345. https://doi.org/10.1021/ja00061a049.

[14] S.M. Malinak, A.M. Simeonov, P.E. Mosier, C.E. McKenna, D. Coucouvanis, J. Am. Chem. Soc. 119 (1997) 1662-1667. https://doi.org/10.1021/ja963475s.

[15] D. Coucouvanis, J. Han, N. Moon, J. Am. Chem. Soc. 124 (2002) 216-224. https://doi.org/10.1021/ja0110832.

[16] M. Koutmos, I.P. Georgakaki, D. Coucouvanis, Inorg. Chem. 45 (2006) 3648-3656. https://doi.org/10.1021/ic052156b.

[17] A. Kay, P.C.H. Mitchell, J. Chem. Soc. Inorg. Phys. Theor. (1970) 2421-2428. https://doi.org/10.1039/J19700002421.

[18] A. Kay, P.C.H. Mitchell, Nature. 219 (1968) 267-268. https://doi.org/10.1038/219267a0.

[19] B. Spivack, Z. Dori, J. Chem. Soc. Chem. Commun. (1970) 1716-1717. https://doi.org/10.1039/C29700001716.

[20] V.R. Ott, D.S. Swieter, F.A. Schultz, Inorg. Chem. 16 (1977) 2538-2545. https://doi.org/10.1021/ic50176a024.

[21] F.A. Schultz, V.R. Ott, D.S. Rolison, D.C. Bravard, J.W. McDonald, W.E. Newton, Inorg. Chem. 17 (1978) 1758-1765. https://doi.org/10.1021/ic50185a011.

[22] N.C. Howlader, G.P. Haight, T.W. Hambley, M.R. Snow, G.A. Lawrence, Inorg. Chem. 23 (1984) 1811-1815. https://doi.org/10.1021/ic00181a007.

[23] Ramgopal. Bhattacharyya, P.K. Chakrabarty, P.N. Ghosh, A.K. Mukherjee, Debi. Podder, Monika. Mukherjee, Inorg. Chem. 30 (1991) 3948-3955. https://doi.org/10.1021/ic00020a031.

[24] J.M. Gretarsdóttir, S. Bobersky, N. Metzler-Nolte, S.G. Suman, J. Inorg. Biochem. 160 (2016) 166-171. https://doi.org/10.1016/j.jinorgbio.2016.01.020.

[25] E. Cadot, M.N. Sokolov, V.P. Fedin, C. Simonnet-Jégat, S. Floquet, F. Sécheresse, Chem. Soc. Rev. 41 (2012) 7335-7353. https://doi.org/10.1039/C2CS35145E. 
[26] J.-F. Lemonnier, S. Duval, S. Floquet, E. Cadot, Isr. J. Chem. 51 (2011) 290-302. https://doi.org/10.1002/ijch.201100009.

[27] H.E. Moll, J.C. Kemmegne-Mbouguen, M. Haouas, F. Taulelle, J. Marrot, E. Cadot, P. Mialane, S. Floquet, A. Dolbecq, Dalton Trans. 41 (2012) 9955-9963. https://doi.org/10.1039/C2DT30534H.

[28] A. Hijazi, J.C. Kemmegne-Mbouguen, S. Floquet, J. Marrot, J. Fize, V. Artero, O. David, E. Magnier, B. Pégot, E. Cadot, Dalton Trans. 42 (2013) 4848-4858. https://doi.org/10.1039/C2DT32447D.

[29] Floquet S., Cadot E, Hijazi A, Gulea A, Japcov V., Bulimaga V., Zosim L., Rudic V., Hidrat de bis[(iminodiacetat)oxotiomolibdat( $\mathrm{V})$ ] de tetrafenilfosfoniu şi procedeu de cultivare a microalgei Spirulina platensis cu utilizarea acestuia. Brevet de invenţie nr MD 4319 2015.01.31, BOPI nr. 1/2015, MD4319, 2015.

[30] B. Kamenar, B. Kaitner, N. Strukan, Croat. Chem. Acta. 64 (1991) 329-341.

[31] W.S. McDonald, Acta Crystallogr. B. 34 (1978) 2850-2853. https://doi.org/10.1107/S0567740878009371.

[32] Z.-H. Zhou, Q. Xu, J. Lin, S.-W. Ng, Inorg. Chem. Commun. 10 (2007) 1461-1464. https://doi.org/10.1016/j.inoche.2007.09.006.

[33] S. Duval, S. Floquet, C. Simonnet-Jégat, J. Marrot, R.N. Biboum, B. Keita, L. Nadjo, M. Haouas, F. Taulelle, E. Cadot, J. Am. Chem. Soc. 132 (2010) 2069-2077. https://doi.org/10.1021/ja909762p.

[34] K. Mukherjee, P. Roychowdhury, K. Roy, D. Mukherjee, M. Kusunoki, Acta Crystallogr. C. 51 (1995) 32-34. https://doi.org/10.1107/S0108270193012168.

[35] D.-M. Li, Y.-H. Xing, Z.-C. Li, J.-Q. Xu, W.-B. Song, T.-G. Wang, G.-D. Yang, N.-H. Hu, H.-Q. Jia, H.M. Zhang, J. Inorg. Biochem. 99 (2005) 1602-1610. https://doi.org/10.1016/j.jinorgbio.2005.04.020.

[36] H. Liu, G.J.B. Williams, Acta Crystallogr. B. 37 (1981) 2065-2067. https://doi.org/10.1107/S056774088100798X.

[37] P.-F. Wu, D.-S. Li, X.-G. Meng, X.-L. Zhong, C. Jiang, Y.-L. Zhu, Y.-G. Wei, Acta Crystallogr. Sect. E Struct. Rep. Online. 61 (2005) m1553-m1555. https://doi.org/10.1107/S1600536805021732.

[38] B. Spivack, Z. Dori, J. Chem. Soc. Dalton Trans. (1975) 1077-1080. https://doi.org/10.1039/DT9750001077.

[39] E. Cadot, B. Salignac, J. Marrot, A. Dolbecq, F. Sécheresse, Chem. Commun. (2000) 261-262. https://doi.org/10.1039/A909024J.

[40] F. Sécheresse, A. Dolbecq, P. Mialane, E. Cadot, Comptes Rendus Chim. 8 (2005) 1927-1938. https://doi.org/10.1016/j.crci.2005.02.036.

[41] S. Floquet, S. Brun, J.-F. Lemonnier, M. Henry, M.-A. Delsuc, Y. Prigent, E. Cadot, F. Taulelle, J. Am. Chem. Soc. 131 (2009) 17254-17259. https://doi.org/10.1021/ja9052619.

[42] N. Watfa, D. Melgar, M. Haouas, F. Taulelle, A. Hijazi, D. Naoufal, J.B. Avalos, S. Floquet, C. Bo, E. Cadot, J. Am. Chem. Soc. 137 (2015) 5845-5851. https://doi.org/10.1021/jacs.5b01526.

[43] A. Jemal, F. Bray, M.M. Center, J. Ferlay, E. Ward, D. Forman, CA. Cancer J. Clin. 61 (2011) 6990. https://doi.org/10.3322/caac.20107.

[44] R.K. Jain, Sci. Am. 310 (2014) 46-53. https://doi.org/10.1038/SCIENTIFICAMERICAN0214-46.

[45] L. Ashford, Y. Collymore, Preventing cervical cancer worldwide, Population Reference Bureau, 2005

[46] A.R.P. Hinson, R. Jones, L.E.S. Crose, B.C. Belyea, F.G. Barr, C.M. Linardic, Front. Oncol. 3 (2013). https://doi.org/10.3389/fonc.2013.00183.

[47] Www.Cancer.Ca. (n.d.). https://www.cancer.ca:443/en/about-us/news/national/2015/tacklingthe-most-difficult-cancers/?region=on (accessed August 11, 2020).

[48] S.S. Costa, E. Junqueira, C. Palma, M. Viveiros, J. Melo-Cristino, L. Amaral, I. Couto, Antibiotics. 2 (2013) 83-99. https://doi.org/10.3390/antibiotics2010083.

[49] B. Spivack, Z. Dori, J. Chem. Soc. Chem. Commun. (1973) 909-910. https://doi.org/10.1039/C39730000909. 
[50] B. Spivack, Z. Dori, J. Chem. Soc. Dalton Trans. (1973) 1173-1177.

https://doi.org/10.1039/DT9730001173.

[51] W.E. Newton, J.L. Corbin, J.W. McDonald, J. Chem. Soc. Dalton Trans. (1974) 1044-1049. https://doi.org/10.1039/DT9740001044.

[52] F.A. Armstrong, T. Shibahara, A.G. Sykes, Inorg. Chem. 17 (1978) 189-191. https://doi.org/10.1021/ic50179a036.

[53] A. Nakamura, M. Nakayama, K. Sugihashi, S. Otsuka, Inorg. Chem. 18 (1979) 394-400. https://doi.org/10.1021/ic50192a040.

[54] D. Coucouvanis, A. Toupadakis, A. Hadjikyriacou, Inorg. Chem. 27 (1988) 3272-3273. https://doi.org/10.1021/ic00292a005.

[55] R. Llusar, S. Triguero, C. Vicent, M.N. Sokolov, B. Domercq, M. Fourmigué, Inorg. Chem. 44 (2005) 8937-8946. https://doi.org/10.1021/ic0508728.

[56] T. Shibahara, S. Ogasahara, G. Sakane, Acta Crystallogr. Sect. E Struct. Rep. Online. 64 (2008) m605-m606. https://doi.org/10.1107/S1600536808007757.

[57] E.C. Kendall, F.F. Nord, J. Biol. Chem. 69 (1926) 295-337.

[58] L.B. Poole, Free Radic. Biol. Med. 0 (2015) 148-157. https://doi.org/10.1016/j.freeradbiomed.2014.11.013.

[59] W.H. Pan, M.A. Harmer, T.R. Halbert, E.I. Stiefel, J. Am. Chem. Soc. 106 (1984) 459-460. https://doi.org/10.1021/ja00314a054.

[60] J.C. Kemmegne-Mbouguen, S. Floquet, D. Zang, A. Bonnefont, L. Ruhlmann, C. Simonnet-Jégat, X. López, M. Haouas, E. Cadot, New J. Chem. 43 (2019) 1146-1155. https://doi.org/10.1039/C8NJ04451A.

[61] A. Misra, I. Franco Castillo, D.P. Müller, C. González, S. Eyssautier-Chuine, A. Ziegler, J.M. de la Fuente, S.G. Mitchell, C. Streb, Angew. Chem. Int. Ed. 57 (2018) 14926-14931. https://doi.org/10.1002/anie.201809893.

[62] P.S. Chubik, L.N. Nechaeva, V.I. Brylin, METHOD OF DETERMINING TOXICITY OF CHEMICAL SUBSTANCES IN AQUEOUS MEDIA. Patent RU2112977C1, Tomskij politekhnicheskij universitet, RU2112977C1, 1998.

[63] P. Madoni, M.G. Romeo, Environ. Pollut. 141 (2006) 1-7. https://doi.org/10.1016/j.envpol.2005.08.025.

[64] Н.С. Лотова, in: Студенческая Наука XXI Века, ЦНС «Интерактив плюс», Чебоксары, 2015: pp. 20-22. https:/interactive-plus.ru/ru/article/12856/discussion_platform.

[65] E. Roșcov, A. Gulea, I. Toderaș, O. Garbuz, SUM. 6(96) (2016) 164-169.

[66] I.C. Toderaş, A.P. Gulea, E.V. Roscov-Arcan, O.S. Garbuz, Bul. Acad. Ştiinţe Mold. Ştiinţ. Vieţii. 330 (3) (2016) 109-115.

[67] M.A.B. Habib, Review on culture, production and use of Spirulina as food for humans and feeds for domestic animals and fish, Food and Agriculture Organization of the United Nations, 2008. https://agris.fao.org/agris-search/search.do?recordID=US201300135032 (accessed August 29, 2020).

[68] S. Djur, Analele Univ. Din Oradea Fasc. Biol. XXVI (2019) 51-56.

[69] L. Cepoi, T. Chiriac, L. Rudi, S. Djur, L. Zosim, V. Bulimaga, L. Batir, D. Elenciuc, V. Rudic, in: Recent Adv. Trace Elem., John Wiley \& Sons, Ltd, 2018: pp. 403-420. https://doi.org/10.1002/9781119133780.ch19.

[70] V. Rudic, Phycobiotechnology-fundamental research and practical achievements, „Elena - V.I." SRL, Chisinau, 2007. 